\title{
Exploring the Intellectual Foundation of Technology Education: From Condorcet to Dewey
}

\author{
Randy Chafy
}

Since the colonial era, Western institutionalized education increasingly has been put into the service of civilization-building by seeking to advance practical industrial needs. But education has not always had such an explicitly economic orientation. In the early Middle Ages, the purpose of education was conceived of primarily in terms of advancing spiritual well-being, Church- or State-sponsored occupations, and socially "proper" forms of knowledge. Only as European nations embarked upon colonial expansion did education begin to become associated with citizenship, nation-building, practical and secular knowledge, and the advancement of a technological civilization and private enterprise. As a result, since the eighteenth century, this second school of educational thought has become increasingly dominant in educational thought and practice.

Our contemporary understanding of science and technology education (referred to here simply as "technology education") owes much to Enlightenment-based assumptions on the nature of civilizational advancement. These assumptions are illustrated in the writings of formative educational thinkers during the eighteenth and nineteenth centuries, especially the works of Antoine-Nicholas de Condorcet and John Dewey. In examining their beliefs, I am not seeking to merely provide only an overview of educational thought but to bring into question certain fundamental assumptions embedded in the historical development of technology education. Although I acknowledge the theme of "education for citizenship" as an Enlightenment ideal that helped to generate mass education, I am more concerned with exploring the validity of using technological advancement as a benchmark of civilizational progress - an ideological belief that continues to be implicated within non-critical approaches to technology education. Put another way, I see a problematic (and limiting)

Randy Chafy is a Business Maturity Consultant for Northern Telecom, Ottawa, Ontario. He received his Ph.D. from Michigan Technological University in 1996. 
conceptual linkage between technology, education, civilization-building, industrial growth, and human purpose. ${ }^{1}$

\section{Education, Technology, and Condorcet}

Throughout the Middle Ages, the Renaissance, and the Reformation, nearly all technological innovations took place on an individual craft basis; knowledge was transferred from generation to generation by apprenticeship. Significant technological advancements, such as the clock, the horizontal axle windmill, gigantic Gothic cathedrals, the printing press, and better guns and ships, were being developed outside of the universities. But these advancements, by themselves, did not cause Europeans to rethink their then-dominant understanding of human purpose in relation to spiritual perfection. Nor did the outward expansion of the market economy, which has frequently been identified as the most significant force leading to the Industrial Revolution (particularly in Marxist perspectives), cause Europeans to rethink their lofty status. The growth of the market economy is often tied closely to the growth of secular institutions, government bureaucracies, the availability of raw materials, and early trade with, later exploitation of, non-Western societies. All of these elements, it has been argued, somehow worked together to convince Europeans of the merits of industrialization; that the same development did not occur outside of Europe appears to merely reinforce this perspective. What is generally overlooked, however, is how the Europeans' growing knowledge of distant cultures helped to change their worldview of themselves and their relation to the physical world and other cultures. The Enlightenment was one result of this new orientation; another was the Industrial Revolution; and still another was a growing emphasis on the merits of technology education.

Throughout the seventeenth and eighteenth centuries, higher education in Europe and the emerging power of the United States retained a classical format. The first broadly based engineering university would not be founded until the Ecole Polytechnique was established in France in 1794. During these two centuries, however, Europeans increased their trade and colonial interactions with less technologically advanced cultures, and began to recognize their own cultural superiority in terms of technological achievements. As a result, a fundamental reorientation was beginning to take place concerning the role of technology and the purpose of education in European society.

The French Enlightenment of the eighteenth century built upon the ideas of Francis Bacon and his contemporaries. The Enlightenment was a rejection of both realism and the idea that the greatness of humankind rested in ancient knowledge. While all Enlightenment thinkers believed in certain basic principles, namely, the inherent goodness of humankind, the right to a democratic society, and that civilization must advance through technological progress to a more advanced state of being, only Jean-Jacques Rousseau and

${ }^{1}$ For insightful overview on the idea of progress, including the "progress system," see Almond (1982). 
Antoine-Nicholas de Condorcet focused on education to any degree, and Condorcet was arguably the more thorough and influential of the two.

During mid-eighteenth century France, education was targeted at the elite, dominated by the Church, and unavailable for most of the population. The universities of France, as in most of Europe, still regarded law, medicine, and theology as the only relevant disciplines in the classical study framework; the Catholic Church and its cohort the French monarchy retained an ever-weakening hegemony in a declining and battle-weary French state. Great Britain was becoming a formidable power in Europe, and would further enhance its position by giving birth to the Industrial Revolution in the middle of the century. On the other hand, late-eighteenth century France, like Germany and the United States, was becoming increasingly "backward" by comparison, and education was beginning to be seen as a way to catch up with the British. In 1791-92, Condorcet presented a plan for a universal form of education to the French Legislative Assembly, proposing a "complete national system of secular schools to provide equal opportunity for all children, free, compulsory and universal" (Butts, 1973, p. 350). His plan was rejected at the time, but he put in place germinal ideas for mass education that later would be used in educational planning in France, Germany, and the United States.

Condorcet, like other Enlightenment thinkers, believed that there was no limit to the learning capabilities of the human mind and that progress meant the perfection of science and technology. He also believed that all "men" are products of nature, with equal rights bestowed upon them to the moral, practical, and intellectual pursuits of reason. Human progress, in his view, rested on an individual's ability to educate and refine himself in those three areas of human action. Since colonization had proven the "superiority" of Western technology, such knowledge should be spread to all through the liberating power of education.

In 1793, Condorcet wrote his great essay, Sketch for a Historical Picture of the Progress of the Human Mind; in it, he argued that the human mind must progress from irrationality to rationality, from superstition to reason, from prescientific thought to scientific enlightenment. Progress constitutes ten stages of human development, or "civilization." The first stage of civilization is the "savage" tribe, dependent on hunting, fishing, crude weapons, and simple utensils, with little government bureaucracy and only a "small number of moral ideas" (Condorcet, 1955, p. 5). Condorcet viewed the African tribe as representative of this first stage of human development, while he placed European-based societies further up the evolutionary ladder:

Will all nations one day attain that state of civilization which the most enlightened, the freest and the least burdened by prejudices, such as the French and Anglo-Americans, have attained already? Will the vast gulf that separates these peoples from the slavery of nations under the rule of monarchs, from the barbarism of African tribes, from the ignorances of savages, little by little disappear? (Condorcet, 1955, p. 174). 
For Condorcet, as a culture moves from one stage to the next, it develops more advanced technologies and bureaucratic political systems, and exhibits more personal freedoms and democratic principles.

Condorcet's tenth stage of civilization, the last and the greatest, is marked by liberty, equality, democracy and universal education for all. Of all these social developments, education is the most significant to Condorcet because it is the key to all forms of human progress: "With greater equality of education there will be greater equality in industry and so in wealth; equality in wealth necessarily leads to equality in education: and equality between nations and equality within a single nation are mutually dependent" (Condorcet, 1955, pp. 183-84). Thus, a "well directed system of education" will result in "progress" in its most basic form and "the absolute perfection of the human race" (Condorcet, 1955, p. 184). Through education, the citizen of the masses might, among other things, be taught to manage their own households, to know their rights and to exercise those rights, to be empowered in the face of those who possess authority, to overcome ignorant prejudices, to use reason to overcome superstition, and to advance the technological arts (Condorcet, 1955, pp. 18284). Furthermore, Condorcet recognized the need for a linkage between science and the technological arts in education:

If we turn now to the arts, whose theory depends on [the] sciences, we shall find that their progress depending as it does on that of theory, can have no other limits; that the procedures of the different arts can be perfected and simplified in the same way as the methods of the sciences; new instruments, machines and looms can add to man's strength and can improve at once the quality and the accuracy of his productions, and can diminish the time and labour that has to be expended on them. The obstacles still in the way of this progress will disappear, accidents will be foreseen and prevented, the insanitary conditions that are due either to the work itself or the climate will be eliminated (Condorcet, 1955, p. 187).

Given this faith in technology, Condorcet not surprisingly blended his understanding of education, technological progress, and reason with morality and happiness. Human reason and logic, which always work for the betterment of humankind, are responsible for keeping technological development on track. Although technological development might have limits (such as through overpopulation and the lack of food), human reason will solve those problems:

But even if we agree that the limit will one day arrive, nothing follows from it that is in the least alarming as far as either the happiness of the human race or its indefinite perfectibility is concerned;... we can assume that by then men will know that, if they have a duty towards those not yet born, that duty is not to give them existence but to give them happiness; their aim should be to promote the general welfare of the human race or of the society in which they live or of the family to which they belong, rather than foolishly to encumber the world with useless and wretched beings (Condorcet, 1955, p. 189). 
Thus, Condorcet predicted that reason would somehow progress far enough to provide the moral grounding necessary to avoiding overpopulating the world with "useless and wretched beings." Progress, reason, science, technology, and knowledge would collapse into one unified, determining force, since these are the foundations for morality.

Finally, while Condorcet condemned the ignorant prejudices of his day, what he called the "murderous contempt for men of another colour or creed," he was a firm proponent of the civilizing mission of the West. He believed that the Europeans had a duty to civilize those "savage nations who still inhabit vast tracts of land" (Condorcet, 1955, p. 175). European missionaries and their "superstitions," he predicted, would disappear, as would the existing practices of trade and colonialism for greed and profit. Instead, enlightened, newly appointed European trade representatives would be assigned to colonial outposts to act as "liberators" to the uncivilized lands of the world; teachers to educate the ignorant:

These vast lands are inhabited partly by large tribes who need assistance from us to become civilized, who wait only to find brothers amongst the European nations to become their friends and pupils; partly by races oppressed by sacred despots or dull-witted conquerors, and who for so many centuries have cried out to be liberated; partly by tribes living in a condition of almost total savagery in a climate whose harshness repels the sweet blessings of civilization and deters those who would teach them its benefits; and finally, by conquering hordes who know no other law but force, no other profession but piracy. The progress of these two last classes of people will be slower and stormier; and perhaps it will even be that, reduced in number as they are driven back by civilized nations, they will finally disappear imperceptibly before them or merge into them (Condorcet, 1955, p. 177).

Cloaked in Condorcet's colorful prose, the preceding passage advances the notion of European "civilized" cultural superiority. And, although Condorcet condemned the "sacred despots or dull-witted conquerors" of the "oppressed" tribal cultures, he failed to acknowledge the impact of European tyrants. Ironically, the average European peasant was arguably no more liberated than the tribal cultures he criticized.

Condorcet's text was published and widely read after his death in 1794, and his ideas began to be put into practice in the early nineteenth century. But the Enlightenment emerged at a violent time in French and European history, and Condorcet himself was imprisoned as an aristocrat during the French Revolution and died shortly thereafter. Furthermore, the Catholic and Protestant Churches remained powerful stabilizing forces well beyond the Enlightenment and into the nineteenth century. Thus, although Condorcet and the other Enlightenment thinkers had only a minor immediate impact on education in Europe, they planted important seeds of change that would ultimately transform the theory and practice of European and American institutionalized education. 


\section{The Development of Technology education in the United States}

The model for what can now be called "mass" education was put into place by the four Western modernizing powers of the last two centuries: Great Britain, France, Germany, and the United States. The educational systems developed by these nations helped them to realize Condorcet's vision of education, that is, mass education with a technological orientation. Although several factors played a role in the emergence of technology education-the development of the nation-state, the expansion of the market economy, the weakness of the Catholic Church, and other tangible factors - the Enlightenment represented a more crucial repositioning of civilizational advancement. Viewed in these terms, the Industrial Revolution was both a practical manifestation of this changing orientation and a foundational moment in history which helped stimulate other nations to modernize. To illustrate these assertions, I will consider some key points in the development of technology education in the United States in the post-Enlightenment era.

Although the United States is more heavily endowed with natural resources than any of its European counterparts, its ascent to economic superpower over the last century owes much to the expansion of technology education, particularly at the university level. ${ }^{2}$ Since the American Revolution of 1776, one of the most dominant and recurrent themes in American educational philosophy has been the motif of Condorcet's concept of "education for citizenship," or education as the right of the people. Prominent educational historian R. Freeman Butts notes, "One of the most far-reaching results of Enlightenment theories of education was the development of education for citizenship" (Butts, 1955, p. 291). Owing much to Enlightenment thought, this theme has also been linked to other Enlightenment ideals, such as the value of natural science, progress, and technological advancement.

From its beginnings, unlike the German version of education as "enlightenment from above," educational practice in the United States exemplified the principle of "enlightenment from below" - the establishment of a universal, free, and compulsory education program under the control of public organizations. Following the American Revolution, Thomas Jefferson, a former ambassador to France sympathetic to early French Enlightenment thought, became the most formidable spokesperson for a state-supported free and universal educational system, and science was one key component of his proposed educational curriculum. As a starting point, Jefferson introduced his plan to the Virginia legislature in 1779, where, just as Condorcet would later experience in France, it failed to receive enough votes for approval. Subsequently, American education would remain in the hands of private parties, primarily the Church, until well into the nineteenth century. But Jefferson sparked a debate around the purpose of education, and his influence closely paralleled Condorcet's in Europe. By 1818, he had successfully introduced bills

${ }^{2}$ Some of the most engaging histories of education in America include Smith (1990), Button (1983), Meyer (1967), Butts (1953), and the controversial Noble (1977). 
that led to the founding of the University of Virginia and the reorganization of William and Mary (Heslep, 1968, p. 97).

American historian Page Smith has characterized the legacy of Jefferson as introducing an ongoing tension between two forms of "consciousness" that have shaped American educational theory and practice. The first, what he calls the "Classical Christian Consciousness," and what the American Constitution was based on, embodies the long-standing tradition of an ordered universe governed by natural laws and laws governing human beings as defined by God Himself. This consciousness held that "the best thought and experience of the race was a precious heritage that must be preserved as a vital part of the consciousness of the new nation" (Smith, 1990, p. 35). This consciousness was evident in the long-standing dominance of classical education, with its religious underpinnings and elite nature.

Conversely, the "Secular Democratic Consciousness" embodies the values of the Enlightenment and is characterized by a "faith in limitless progress through reason and science" and "the natural goodness of man once he was free from superstition/religion" (Smith, 1990, pp. 29-30; 35). The Secular

Democratic Consciousness, with Jefferson as its leading spokesperson, would eventually become the predominant consciousness, in spite of the dogma of the early classical college system in America. The new consciousness was initially aided by the pragmatic, skill-oriented teachings of Noah Webster's spelling and grammar books in the late-eighteenth century, the introduction of McGuffey's Readers in 1836, and many other similar texts that celebrated American knowledge and sought to create "traditional American values" (and I cringe at using such an expression) (Button, 1983, pp. 120-21). McGuffey's Readers eventually sold 100 million copies and for over half a century served as the "principal reading matter" for rural America; young American's were "dazzled" with such stories as "Washington and His Little Hatchet" and "Woodman Spare That Tree" (Meyer, 1967, p. 200). The values espoused by the Readers were as much Victorian as American, but they served to inspire "patriotic and moral values" and "loudly proclaimed the glories of resourcefulness and the sadness of indolence" (Butts \& Cremin, 1953, p. 274). Yet, the Classical Christian Consciousness remained dominant in education throughout the nineteenth century, and distinct core curriculums, such as programs in engineering and science, and professional majors did not commonly appear until near the turn of the twentieth century. Smith notes that the debate between these two schools of thought "has, indeed, been continual throughout the history of the republic and goes on scarcely diminished to the this day" (Smith, 1990, p. 35).

Responding to Jeffersonian and pragmatic ideals, by the middle of the nineteenth century, a rising chorus of voices began calling for a public education system, voices including Horace Mann, James G. Carter, Henry Barnard, Calvin Stowe, Caleb Mills, John D. Pierce, Ninian Edwards, Calvin Wiley, and Charles F. Mercer. Foremost among these men was Horace Mann, who was one of the first to put into place a free state educational system for primary schools. Writing in 1847, Mann advanced the "natural rights" theme of Condorcet and argued that education was the "absolute right of every human being that comes into the world" (Mann, 1971, p. 35). Mann held that institutionalized, 
government-supported free education should be the responsibility of each successive generation (Mann, 1971, p. 46). Mann's ideas were influential in moving education away from the lingering classical education for the elites to public education for the masses.

Although aspects of Enlightenment science-including the ideas of Descartes, Newton, Copernicus, Galileo, and Kepler-crept into the curriculums of traditional institutions such as Harvard beginning in the early eighteenth century, technological university-level institutions did not appear for another 100 years. Finally, in the early nineteenth century, Rensselaer Polytechnic Institute and West Point were founded (Noble, 1977, pp. 22-23). At first, these schools were regarded as less prestigious than their classical counterparts. By mid-century, however, "catching up" to the European powers became an increasing concern as "the clamor of the modernizers became more insistent, claiming that economic development, industrialization, and urbanization required more and more highly trained manpower" (Butts, 1973, p. 424). Soon, other initiatives were expanding the opportunities for technological university education, and by 1860, Michigan, Maryland, and Pennsylvania had established agricultural schools (Butts, 1973, p. 424).

The voices of modernization reform grew increasingly stronger from then on, as industrialists pushed more fervently for political changes in higher education funding. By 1862, already twenty institutions could be accurately called "scientific schools," but these were insufficient to meet corporate needs. Industrialists' strongly lobbied Congress for more technically oriented schools, and their efforts resulted in the passage of the Morrill Act in 1862 (Ross, 1969, p. 44-45). The Act granted federal aid in support of state colleges in agriculture and engineering "in order to promote the liberal and practical education of the industrial classes in the several pursuits and professions of life" (Ross, 1969, p. 46). To encourage the rapid building of these schools, a state was required to found a college within five years of the act to secure a grant (Ross, 1969, p. 47). In 1890, a second Morrill Act was passed with similar guidelines. As a direct result of these reforms, by 1880 there were 85 college-level engineering schools in the country; by 1917, there were 126 . And the annual number of engineering graduates rose from 100 in 1870 to 4300 by the onset of World War I (Noble, 1977, p. 24).

Beginning in the late nineteenth century, one the most powerful calls for modernization, and one that deserves special attention, came from the educational philosophy of John Dewey. Dewey, who would later be highly influential to Chinese and Japanese educators in the early twentieth century, ${ }^{3}$ rallied against the lingering dominance of elite and classical education. Deservedly, Dewey is often credited with leading the final assault on American religious and classical education: "As the nineteenth century turned into the twentieth century the experimentation of John Dewey and his followers made it

${ }^{3}$ In 1919-21, Dewey performed a lecture tour in China that inspired many intellectuals to embrace his progressive ideas and his belief that the West embodied "an ideal of science and progress to which China should aspire" (Thompson, 1969, p. 131). 
even more difficult for advocates of a closed intellectual system and conventional body of truth to hold their own" (Butts, 1973, p. 471). In addition, Dewey is still regarded today as the proponent of democratic education and education for citizenship philosophies.

Building upon the ideals of Condorcet, Jefferson, and Mann, Dewey wrote in his 1900 essay "Schooling as a Form of Community Life" that school should be thought of as a "miniature community, an embryonic society" (Dewey, 1964, p. 306). As such, Dewey recognized the need for a more "cultural" education, one that combined theory and practice, to help create more well-rounded, intelligent, and adaptable citizens:

When the school introduces and trains each child of society into membership within such a little community, saturating him with the spirit of service, and providing him with the instruments of effective selfdirection, we shall have the deepest and best guaranty of a larger society which is worthy, lovely, and harmonious (Dewey, 1964, p. 311).

These general themes throughout Dewey's writings have been continuously resurrected in educational thought and criticism. Dewey's thinking was, and still is, influential in helping to sustain an institutionalized Western education system that would not merely teach skills for a narrowly defined job or function, but also included education for citizenship and experience.

At the root of Dewey's pedagogy is his philosophy of science, a belief that the scientific methodology can be interpreted or translated into educational theory and practice, as well as in terms of human activity. This point has been de-emphasized in many of the more celebratory accounts of Dewey's pedagogy, but it is equally critical to understanding his broad outlook on educational purpose and progress:

For more than fifty years Dewey was the chief apostle of modernity in American philosophy as well as in American education....He argued that schools should strive to emphasize moral goals based upon democratic civic and social experience, vocational and practical usefulness, and individual development in light of the rapid modernizing changes that were taking place in Western civilization (Butts, 1973, p. 471).

Central to Dewey's thinking are the ideas of "logical" reflective thought and objectivity. Everything is subject to objective scientific scrutiny, including morality and values as well as scientific and practical affairs (Dewey, 1964, p. xix). In fact, working from the Enlightenment as a basis, Dewey refers to knowledge and morality as virtually identical concepts: "Actively to participate in the making of knowledge is the highest prerogative of man" (Dewey, 1964, p. 192). For Dewey, these beliefs are critical to human purpose, and all stem from his firm commitment to the scientific methodology: "One of the only two articles that remain in my creed of life is that the future of civilization depends upon the widening spread and deepening hold of the scientific habit of mind" (Dewey, 1964, p. 191). 
At a deeper level, Dewey's perspective on civilizational advancement reflects the Enlightenment bias towards progress and "civilized" versus "savage" cultures. Dewey thus might be characterized as Condorcet's interpreter:

A savage who has been shipwrecked on a river may note certain things that serve him as signs of danger in the future. But civilized man deliberately makes such signs; he sets up in advance of any particular shipwreck warning buoys, and builds lighthouses where he sees signs with great expertness; civilized man institutes a weather service by which signs are artificially secured and information is distributed in advance of the appearance of any signs that could be detected with special methods. A savage finds his way skillfully through a wilderness by reading obscure indications; civilized man builds a highway that shows the road to it all (Dewey, 1964, p. 214).

Although Dewey is saying civilized man uses technology to expand the capabilities inherent in the savage, and is therefore apparently not as harsh as Condorcet, he nonetheless makes a clear distinction between civilized-advanced and uncivilized-primitive based upon relative measures of technological development.

Building "civilization" is important to Dewey, and throughout his writings there is a recurrent preoccupation with the positive aspects of functional, practical tasks - the core of his educational philosophy. For Dewey, only by engaging in and thereby experiencing functional tasks, with scientific understanding, does education become truly meaningful:

The occupation supplies the child with a genuine motive; it gives him experience at first hand; it brings him into contact with realities. It does all this, but in addition it is liberalized throughout by translation into its historic and social values and scientific equivalent. With the growth of the child's mind in power and knowledge it ceases to be a pleasant occupation merely and becomes more and more a medium, an instrument, an organand is thereby transformed (Dewey, 1964, p. 306).

The pedagogy of Dewey boils down to what he calls the "project method," or the active intellectual pursuit of a project and its scientific basis. Linking scientific theory and technological practice is the key component in Dewey's recommendations on education. Arousing "intellectual interest" is therefore understood by Dewey purely in terms of scientific interest; the net result being that "Theoretical subjects will become more practical, because more related to the scope of life; practical subjects will become more charged with theory and intelligent insight. Both will be vitally and not just formally unified" (Dewey, 1964, p. 425).

In the end, Dewey's legacy is as a key figure in reflecting the undercurrents of turn-of-the-century industrial America, and informing and predicting the growth of the technical disciplines in modern American education. In the twentieth century, the importance of engineering and other technical occupations 
is signified by the relative prestige of institutions such MIT and the California Institute of Technology. By 1913, the United States had emerged as an industrial power and had replaced Britain as the world leader in coal mining, machine tools, and chemical and automobile production (Roderick \& Stephen, 1978, pp. 153-54). By that time, the ideal of education for citizenship was virtually inseparable, in practice, from education for practical occupations in the service of industrial needs.

\section{Current Trends}

The current direction of educational thought and practice concerning science and technology is a continuation of the historical precedents outlined in this essay; by World War I, all industrial powers were giving high priority to technology education. The cumulation of this trend in the twentieth century is an overvaluation of increasingly functional, professional, and corporate forms of knowledge. The gradual growth of skill-based technology education in the West grew out of an increase in the perceived need for technological advancement and the industrial power-holders need for skilled workers, especially those in engineering and related technical backgrounds. In the twentieth century, all educational disciplines (both technical and non-technical) have been increasingly scrutinized on their "use" value. ${ }^{4}$

In light of the Japanese high-technology competitive advancements and apparent successes in skill-based education, it is not surprising that much contemporary educational literature calls for changes needed to fix the "failing" American education system. Often, the concern in this literature is with developing "correct" educational models that will enhance skill-based learning. Of special importance is more effectively bridging academic and industrial interests, especially in high technology. ${ }^{5}$ This is no better illustrated than by the 1995 educational pilot program of the Malcolm Baldrige Quality Award, an award originally designed exclusively for organizational improvement by profitmaking companies. The pilot program is headed by both industrial and university representatives, and claims to have been "successfully" tested at all levels of education. The goal of the award is to stimulate educational process improvement using criteria very similar to the corporate quality award. "Education" is defined in practical terms—-schools must prove their "effectiveness" through "measurable" results, and "learner-centered" education must account for the "real needs of learners":

Such needs derive from the requirements of the marketplace and the responsibilities of citizenship. Changes in technology and in the national and world economies are creating increasing demands on employees to become knowledge workers and problem solvers, keeping pace with the rapid changes in the marketplace....A learning-centered school needs to

${ }^{4}$ See Noble (1977) for a discussion on the how the social sciences and humanities have also become geared to the needs of industry.

${ }^{5}$ See, for example, Capper \& Jamison (1993) and Levin (1993). 
fully understand and translate marketplace and citizenship requirements into appropriate curricula. (Education, 1995, p. 3)

Given this foundation for "learning," the underlying emphasis throughout the criteria is the urgent need for building closer ties between education and industry.

It is important to recognize, however, that industrial motivations are also linked to a firm faith in technological progress. Thus, to say that technology education has merely been reduced to industrial needs, as may be exemplified most explicitly by the global proliferation of secondary and post-secondary technical institutes, is to too easily reduce the problem to industrial "interference." Furthermore, although Dewey might now argue that such an approach to education is too rigid and narrow, his definition of "creativity" also falls squarely within the scientific and technological framework-one which might be easily adapted to industrial needs. The fact remains that education and industry have nurtured each other, and it would be difficult to define the contemporary purpose of technology education solely in non-industrial terms.

\section{Rethinking Technology education and Social Progress}

Since the late Middle Ages, Western education has become widespread and institutionalized out of a historical need for skills. The process of developing and practicing mass education thus has been closely linked with the expansion of Western technological development and the pursuit of progress.

Consequently, skill-based education has become critical to the survival of all disciplines, and the closer a program of study is allied to servicing the needs of our technology-driven society, the better.

Western education in the West does offer some students (usually graduate students) the prospect of engaging technology from a critical perspective. A host of humanistic philosophers and social historians in Critical Theory, Cultural Studies, Postmodernism, or other philosophy- and history-based schools of thought have brought into question Western technology and progress. But while the practice of technological development in modern Western society marches forward and expands into the third world, the educational attention paid to placing technology into a broader social context is paltry by comparison. Technology studies, as a specific program of study, appears to be just beyond the scope of both the technical and the non-technical disciplines, both of which remain largely content to focus on skill-based education.

Teachers of technology education, in both secondary and higher levels, are in a unique position to directly influence administration, peer, and student perceptions of the role technology in contemporary society. Technology education must seek to go beyond the transmission of the most effective and economic usage of "tools" in modern society to include critical investigations of the social purpose of technology. This means embracing a critical approach to technological issues, considering so-called humanistic and social science 
perspectives on the role of technology in society, ${ }^{6}$ and empowering all students to engage in a critical dialog around technology, progress, education, and the meaning of civilizational advancement.

\section{References}

Adas, M. (1989). Machines as the measure of men: Science, technology, and ideologies of western dominance. Ithaca, NY: Cornell University Press.

Almond, G. A. (1982). Introduction. In G. A. Almond et al, Progress and its discontents (pp. 1-16). Berkeley and Los Angeles, CA: University of California Press.

Button, W. H. (1983). History of education and culture in America. Englewood Cliffs, NJ: Prentice-Hall, Inc.

Butts, R. F. (1955). A cultural history of western education: Its social and intellectual foundations 2nd ed. New York: McGraw-Hill.

Butts, R. F. (1973). The education of the west: A formative chapter in the history of civilization. New York: McGraw-Hill.

Butts, R. F., \& L. A. Cremin. (1953). A history of education in American culture. New York: Holt, Rinehart and Winston.

Capper, C. A., \& M. T. Jamison. (1993). Let the buyer beware: Total quality management and educational research and practice. Educational Researcher, November, 25-30.

Condorcet, A. N. (1955). Sketch for a historical picture of the progress of the human mind (J. Barraclough, Trans.). London: William Clowes and Sons Ltd.

Dewey, J. (1964). John Dewey on education: Selected works (R. D. Archambault, Ed.). New York: Random House.

Education pilot criteria 1995: Malcolm Baldrige National Quality Award (1995). Gaithersburg, MD: National Institute of Standards and Technology.

Heslep, R. D. (1969). Thomas Jefferson and education. New York: Random House.

Levin, B. (1993). School response to a changing environment. Journal of Educational Administration, 31 (2), 4-21.

Mann, H. (1971). Education as a human right. In J. J. Chambliss, Enlightenment and social progress: Education in the nineteenth century (pp. 181-190). Minneapolis: Burgess Publishing.

Meyer, A. E. (1967). An educational history of the American people 2nd ed. New York: McGraw-Hill.

Mumford, L. (1962). Technics and Civilization. New York \& Burlingame: Harcourt, Brace \& World.

Noble, D. (1977). America by design: Science, technology, and corporate capitalism in 20th century America. New York: Alfred A. Knopf.

Roderick, G. W., \& Stephen, M. D. (1978). Education and industry in the nineteenth century. Bungay, Suffolk, Great Britain: Longman.

${ }^{6}$ Excellent starting points might include Mumford (1962), Winner (1977 \& 1986), Adas (1989), as well as Almond (1982). 
Ross, E. D. (1969). Democracy's college: The land-grant movement in the formative state. New York: Arno Press.

Smith, P. (1990). Killing the spirit: Higher education in America. New York: Viking Penguin.

Thompson, J. C., Jr. (1969). While China faced west: American reformers in nationalist China, 1928-1937. Cambridge, MA: Harvard University Press.

Winner, L. (1977). Autonomous technology: Technics out-of-control as a theme in political thought. Cambridge, MA: MIT Press.

Winner, L. (1986). The Whale and the Reactor: A Search for Limits in an Age of High Technology. Chicago: University of Chicago Press. 